\title{
The Future of Graduate Education: What Doth Tomorrow Bring?
}

Troy A. Festervand, (Email: jlf2m@mtsu.edu), Middle Tennessee State University

James R. Lumpkin, (Email: jrlcba@okstate.edu), Oklahoma State University

\begin{abstract}
Future graduate students and graduate education must accept the axiom that personal and professional growth does not exist for a specific and limited period of time. Developing a program or plan for identifying and delivering or acquiring new skills becomes the responsibility and opportunity for graduate programs, students, and alumni alike. Perhaps most importantly, this essay has suggested that graduate education adopt the philosophy of "life-long learning." To some, both educators and the educated, such a perspective is to be avoided, as it will require continuous change. To others, change is just another word for opportunity.
\end{abstract}

\section{INTRODUCTION}

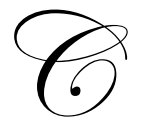

onflict in the Middle-East, September 11, 2001, the digital world, cell phones that would make Dick Tracy envious, global out-sourcing, the "New Economy," and the list goes on and on. In the not so distant past, understanding and responding to any one of these events would have been daunting at the very least. Indeed, the world in which we live and work has become (and continues to become) more complex and demanding. This axiomatic forecast of the future, while not new or particularly insightful, applies to all individuals and institutions, public and private, regardless of locale. Such is the case for institutions of higher learning who must respond to these and many other changes as the metamorphosis of graduate education continues.

Today, all entities are trying to cope with and make sense out of a new set of parameters, that in and of themselves are nebulous at best. For example, the "New Economy" has been described in many ways by many organizations and persons. Defined as a knowledge and idea-based economy, the "New Economy," is an environment where the keys to job creation and higher standards of living are innovative ideas and technology embedded in services and manufactured products. Because its purpose is the creation and transfer of knowledge, higher education (and higher education's products) occupies an integral role in the "New economy's" evolution. ${ }^{1}$ Thus, given the reordering of the world in which we live, the task for higher education is the absolute necessity of identifying and responding to a series of new educational requirements. Institutions of higher learning must redefine the educational product, as well as the requirements/opportunities by which higher education will be delivered (Richards-Wilson 2002).

Higher education consists of about 3,600 firms (institutions of higher education), dispersed geographically and diverse in terms of their educational offerings. These "firms" enroll over 14 million "customers" and have "sales"

\footnotetext{
${ }^{1}$ Perhaps the best example of a New Economy "product" is the Internet. Funded by the Federal government, the Internet was developed with the help of university researchers. Beginning in the late 1960s, the Advanced Research Projects Administration (ARPA), a division of the U.S. Defense Department, developed the Arpanet to link together universities and high-tech defense contractors. Still later, the telecommunications network, that created what is known as the backbone of the Internet, was linked to university computer facilities. Since the 1980s, that function has moved to private, for-profit enterprise, but universities still form an important part of the interlinking of computer networks that form the Internet.
} 
of more than $\$ 200$ billion annually. ${ }^{2}$ Of this total, about 200,000 customers are enrolled in graduate business programs.

In reflecting on this academic challenge, the purpose of this effort is to examine the continuing metamorphosis of graduate education globally. While applicable to all graduate education providers, specific attention is directed toward US institutions. More specifically, the "new environment's" impact on graduate education will be considered in terms of if and how trends in the "new environment" have impacted or will impact the demand for, skills delivered, modes of delivery, educational relationships, and leadership roles, as well as other opportunities and challenges associated with global graduate education.

\section{THE DEMAND FOR GRADUATE EDUCATION IN THE NEW ENVIRONMENT}

Over the past three decades, the number of graduate degrees awarded in the US alone has increased by more than 23 percent. A priori evidence thus appears to indicate that a graduate degree has retained, if not enhanced, its reputation and desirability (Shelley 1997). These gains have been accomplished two ways. First, graduate degrees have succeeded in capturing increasing larger shares of the educational market, despite an increasingly smaller candidate pool National Center for Education Statistics or NCES 1998). Much of this increase is directly attributable to the earnings disparity that exists between graduate and undergraduate degrees. Indeed, the economic incentives for pursuing post-graduate education are powerful. Figures from the NCES (1998) indicate that those with a graduate degree earn almost 28 percent more than those with an undergraduate degree.

More recently, a Forbes magazine study (2001) found that total number of years to achieve breakeven on a graduate degree, while varying by degree type, had fallen from 4.7 in 1990 to 3.3 in 2001 . For graduate degrees earned abroad, the numbers were even more impressive. Lead by IMD/Switzerland, INSEAD/France, and CRANFIELD/England, graduate degrees obtained internationally required less than 3 years to achieve breakeven and generated a 5-year return on investment of over 100 percent. Not surprisingly, enrollment in graduate programs worldwide has responded to these earnings premiums.

Program flexibility is the second factor that has contributed (and will continue to contribute) mightily to the growth in graduate education worldwide. While the "Electronic Age's" prodigy, the Internet, has provided the preponderance of graduate program flexibility, other initiatives such as institutional consortia, exchange programs, international internship programs, and study-abroad programs offer graduate students a range of international flexibility.

The Global eManagement (GEM) program is an executive MBA program that blends concepts and practices of the digital economy with the content found in more traditional EMBA programs. It earns its "global" designation via the active and ongoing involvement of a consortium of universities and professors from around the world who collaborate on curriculum structure and content and by the formation and on-going involvement of global student teams who collaboratively produce responses to global projects. While technology is a central component of the GEM, the program's emphasis is business with global flexibility. ${ }^{3}$

With such collaborative models, a new paradigm for international education appears to have been launched. Collaborative models such as the GEM are not only technologically responsive, but meet the myriad needs of a diverse global student population. Such student-centered responsiveness, in all likelihood, portends the future of higher education in general.

\footnotetext{
2 "Sales" refers to total spending on higher education. Clodfelter (1999).

3 The GEM program has received both EU and G7 approvals, and is the only program to date to receive both approvals. In addition, the program is fully accredited by the European Foundation of Management Education (EFME) in Europe and the American Assembly of Collegiate Schools of Business (AACSB) in the US. http://www.cba.gsu.edu/international/index.html
} 


\section{THE DEMAND FOR NEW SKILLS}

Myers (2000) estimates that the market for electronic education will total $\$ 11.4$ billion by 2003. In response to programmatic and market opportunities, many new curricula directed toward the demands of the "New Economy" have been created. At the graduate level, a number of new degree programs, many of which are cross-cultural in nature, have been developed.

While technological skills often dominant new programs, a skill increasingly demanded of the new generation of graduate students is global in nature. Joseph S. Johnston, Jr. noted in Beyond Borders (1993) that "(g)lobalization is here to stay, and its pace in the foreseeable future will only accelerate." Johnston further noted, "the expansion of the international dimension of higher education is not so much an option as a responsibility."

According to Johnston (1993), the impetus for the increased international emphasis is economics. Two-thirds of American corporations conduct business globally, while over 80 percent of domestically produced goods compete against international products. These percentages are not expected to decline and require unique skill sets (Yang and Diaopin 2001). Thus, to compete successfully in the international marketplace will require international skills, many of which are culture specific. For example, Contreas and Ruff (2002) note that in Latin America, the need for qualified professionals possessing a graduate degree continues to grow, but demands culturally pluralistic international skills. While such skills can best be imparted via an experiential format, it is likely that due to financial and temporal constraints, the foundation for such skills may be delivered in class or via the web, while the true flavor and richness of an international education may occur in the form of an internship or extended study abroad program.

One culture specific skill that historically has proven problematic for US graduate students is language. Because English is the international lingua franca, foreign language skills historically have been de-emphasized. For example, less than 9 percent of US colleges require a foreign language to graduate (Commission on International Education 1998).

While the number and popularity of foreign language courses has increased in recent years, much remains to be done at the graduate level. To meet this need, colleges and universities have a variety of options at their disposal to change a culture of monolingualism. For example, formal coursework, workshops, exchanges, and study abroad programs can help faculty and students acquire and/or develop both language and culture competencies.

With a high degree of certainty, tomorrow's graduate students will find himself/herself operating in an environment that employs increasing amounts of technology and is increasingly global in nature (Richards-Wilson 2002). However, while these skills are critical, the "new environment" will demand skills that transcend traditional and homogenous areas of expertise. For example, future graduates will continue to be trained to function internationally, but that training will become more culture and/or nation specific (i.e., Asia, Latin America, Africa, etc.). Such culture specific training currently is available academically (e.g., the French DESS degree/system offers French graduate students 7 nation specific study programs) and commercially from a number of providers (e.g., http://www.MiddleEastTraining.com). Increasing competition, financial pressures and expectations, and myriad forms of risk will exacerbate the demand for such specificity.

\section{DELIVERY OF THE MBA IN THE NEW ENVIRONMENT}

According to the Wall Street Journal (2000), of 15 million US college students, only one in six fits the traditional age cohort and attends for four consecutive years. Various factors impact this trend. For example, a high percentage of students work while enrolled. The Bureau of Labor Statistics (2000) reports that, among persons 16 to 24 years old, over 50 percent of full-time students and more than 80 percent of part-time students are employed. Similarly, the NCES (1997) reports that 89 percent work at some time while enrolled.

In response, universities have offered courses and degree programs in formats much more flexible than the traditional model. A survey of 1,028 institutions indicates that the percentage offering on-line courses from 48 to 72 
percent (Neal 1999). Worldwide, the number of graduate programs being offered on-line is changing so rapidly, attempts to quantify such are futile.

While there is nothing new about correspondence courses, new forms of "distance learning" increasingly are available. Course delivery now includes traditional mail correspondence courses, television, videotape, two-way teleconferencing, compressed video, and Internet-based courses (Myers 2000). With the advent of new educational and training formats and technologies (i.e., the Internet), distance learning is appealing to the needs of today's learning-hungry, but convenience-oriented students (McAllister and Matthews 2001).

Extant literature on Internet instruction has examined several questions, including course design (Porter 1997; Cooper 2000), student and faculty assessment (Ryan 2000; White 2000), quality control (Lezberg 1998; Terry 2000), and online enrollment, attrition, and success rates (Terry 2001; Yang and Diaopin 2001). Perhaps the most intriguing question involves the quality of such programs. Advocates argue in favor of greater creativity and critical thinking (Bonk and Reynolds 1997), while others (Hart, Svenning, and Ruchinskas 1995; Leidner and Jarvenpaa 1995; Webster and Hackley 1997) argue on behalf of technology's educational effectiveness. On the other hand, Olsen (1999) questions the accreditation of such programs and the impact online programs may have on the quality and quantity of research and other intellectual investments.

Representing a new type of institution is the virtual university such as Capella University (http://www.capellauniversity.edu/), Strayer University (http://www.strayeruniversity.edu), Western Governors University (http://www.wgu.edu/wgu/index.html, and the National Technological University (http://www.ntu.edu/). Perhaps the most widely known virtual institution is the University of Phoenix. Specializing in serving working adults (http://www.phoenix.edu/), this university serves 34 cities and enrolls over 68,000 students from 20+ countries.

Like the University of Phoenix, Capella is an entirely on-line, for-profit operation, while Western Governors University offers no courses of its own. Rather, it coordinates access to the courses of more than 40 colleges, universities, and corporate institutions. Strayer University offers undergraduate and graduate degree programs at 22 campuses and through Strayer University Online to more than 16,500 students throughout the U.S. and worldwide. Having been in operation for over 110 years, Strayer's stated mission is to make quality higher education convenient. Likewise, The National Technological University is a consortium of 52 universities that offer 18 masters degree programs via on-line instruction under the NTU name.

According to the Wall Street Journal (2000), venture capitalists envision on-line education as a cash cow and are trying to lure elite institutions into the business. A number of universities have explored the creation of for-profit subsidiaries to finance the costs (Goldstein 2000) of on-line educational services. ${ }^{4}$ In an article on the status of universities, a British news magazine, The Economist (1997), concluded that "[t]he advent of cyberspace is less likely to destroy the university than to offer it novel ways of reaching out to more students at lower cost. Instead of dismantling the community of scholars, it may give it a new lease on life by creating new connections between academics working in adjacent disciplines and unadjacent places." These connections and/or relationships are likely to include new cultures and generations of students (e.g., China) who thirst after the knowledge and opportunities available through a graduate degree. Because of the physical distance and cost involved, responding to these needs and/or opportunities will demand that new educational alliances be created, course/program delivery will become increasingly multidimensional, and curriculum content will be subject to greater specificity and perpetual redesign.

\section{ACADEMIC AND PROFESSIONAL OPPORTUNITIES/CHALLENGES}

The final section of this essay on graduate education in the "new environment" focuses on academic and professional opportunities/challenges for providers and consumers alike. For example, there is a trend toward expediting the amount of time required to complete the requirements for a graduate degree. Regardless of whether a program is lock-step, part-time, or some educational hybrid, graduate students want and/or demand to complete the

4 “To Be [For-Profit] Or Not to Be" p. 25. 
requirements sooner and more conveniently. While a greater number of delivery modes and programs provided some temporal relief, in other instances, expediting degree attainment could only be achieved by reducing the number of hours required (Dyer, Lasdon, and Ruefli 1998). On-line education, immersion programs, credit-by-exam, life experience credits, etc. all were created largely to satisfy these demands.

While this temporal momentum may appear desirable to both students and providers alike in that it increases what might be considered the inventory turnover rate, given the dynamics and requirements of the "new environment," a valid question appears to be, how can any temporal perspective other than "life-long learning" be embraced? Developing and responding to this opportunity and responsibility is the more relevant long-term question.

In addition to concerns for the adequacy of academic standards, trends such as this raise the question of academic balance. What rule or standard does a graduate program, especially an international one where temporal and financial requirements are especially high, balance the needs (personal and academic) of its students, while satisfying professional obligations in an environment of unprecedented educational opportunity?

Consequently, most higher education pundits foresee tremendous continued growth potential in graduate education, much of which will occur internationally. For example, during the 1990's, "graduate programs multiplied "like kittens." This expansion took place throughout the US, but grew exponentially in other parts of the world, such as Asia and Latin America. Add to these educational growth opportunities university/corporate partnerships, online/for-profit universities, distance-learning initiatives, etc. and the issue of "graduate education commoditization" becomes a threat (Schmotter 2000).

In response to the potential "commoditization," Cranier and Dearlove (1999) argue that college and universities worldwide must adopt two new rules, more self-restraint and the enhancement of academic standards. Further, critics argue that major schools around the globe and their governing bodies assume a more visionary role. Without effective leadership, control, standards, and vision, the fear is that the value of a graduate degree will be compromised.

Newly ordained masters graduates entering the workforce can expect to have from four to six careers in their career (Hall 1996). Thus, future graduates should recognize and accept the proposition that career changes require further personal and professional development. Further, many of the skills and/or tools accompanying such changes will be delivered through continuing education courses (Boyatzis and Kram 2000). Developing and offering continuing education programs represents an emerging role for many universities who previously saw this need or opportunity as being outside their mission statement. This view of the university's role has changed and will continue to change as higher education providers continue to identify and respond to competitive pressures and enhanced revenue opportunities worldwide.

While several retooling and/or personal growth options are available to individuals faced with the need/opportunity for professional change, one of the most desirable and effective approaches may be "self-directed" study. The Weatherhead School of Management at Case Western Reserve University and Boston University's School of Management's Executive Leadership Center provide examples of two programs currently making extensive use of this customized pedagogy. In each instance, executives make extensive use of self-assessment, personal and professional goal-setting, personal reflection, and action directed planning. The results of these activities subsequently are evaluated by the student and a mentor/coach to ascertain their appropriateness, completeness, and effectiveness.

While the success of these programs may be questioned, there appears to be little doubt that at some point, all future graduate degreed individuals will come face-to-face with the need/opportunity to introduce change into their personal and professional lives through a career redirection and associated changes in philosophy, behavior, and skill set (Boyatzis and Kram 2000). These changes are not limited geographically, politically, or culturally bound. 


\section{CONCLUSION}

While graduate education is less than a century old, the institutional forms that have been developed for this type of education have adapted to new technologies and new environments and at an increasingly rapid pace. The demand for knowledge — both the creation of that knowledge and its transfer — is growing. The mechanism(s) that deliver that knowledge will certainly change in response to those demands.

What about the future? In a Futures (1998) symposium, many prophets foresee radical change for all of higher education. Samuel Dunn (2000) predicts that by 2025 traditional universities (thus degrees) may be "a thing of the past ...." The forces compelling or propelling this change include the economy, technology, and globalization. While applicable to all of higher education, these prognostications portend profound change, especially for graduate education.

This essay has focused on the future of graduate education in the "New Economy." It has suggested that at least three major changes/opportunities for universities, graduate programs, and graduate students exist. One such change/opportunity focuses on the role/impact of technology in the delivery of graduate business education. It is incumbent that both parties embrace technology as being a means to an end, as well as an end.

Another future focus appears to be a far more active role internationally. To do so, will require a significantly expanded and culture specific set of skills. In addition to core competency skills, future graduates must acculturate themselves much more fully. This can be accomplished via study-abroad programs, international internships, and global exchanges.

Finally, future graduate students and graduate education must accept the axiom that personal and professional growth does not exist for a specific and limited period of time. Developing a program or plan for identifying and delivering or acquiring new skills becomes the responsibility and opportunity for graduate programs, students, and alumni alike. Perhaps most importantly, this essay has suggested that graduate education adopt the philosophy of "life-long learning." To some, both educators and the educated, such a perspective is to be avoided, as it will require continuous change. To others, change is just another word for opportunity.

\section{REFERENCES}

1. Bonk, C. J. and T. H. Reynolds, Learner-Centered Web Instruction for High-Order Thinking, Teamwork and Apprenticeship in Web Based Instruction, Ed. B. H. Khan. Educational Technology Publications, Englewood Cliffs, N.J. (1997).

2. Boyatzis, Patricia and Kathy E. Kram, Information Technology and Graduate Business Programs, Selections, (Winter 2000), pp. 11-16.

3. Clotfelter, C. T. The Familiar but Curious Economics of Higher Education: Introduction to a Symposium. Journal of Economic Perspectives, 13, 1 (Winter 1999), pp. 13-36.

4. Commission on International Education, What We Can’t Say Can Hurt Us, (April 17, 1998).

5. Contreras, Jose L. and Erich Spencer Ruff, MBA Education in Latin America: The Case of Chile, Journal of Education for Business, 78, 1 (Sept-Oct 2002), 51-56.

6. Cooper, L., Online Courses: Tips for Making Them Work, T.H.E. Journal, 27, 8 (2000), 86-92.

7. Cranier, Stuart and Des Dearlove, Gravy Training: Inside the Business of Business Schools, San Francisco: Jossey-Bass, (1999).

8. $\quad$ Dunn, S. L., The Virtualizing of Education, The Futurist, (March-April 2000), pp. 34-38.

9. Goldstein, M. B., To Be [For-Profit] Or Not to Be: What is the Question?, Change, 33, 5 (SeptemberOctober 2000).

10. Grimes, Ann, A Matter of Degree, Wall Street Journal, (July 17, 2000), p. R29 (E-Commerce Special Supplement).

11. Hall, D. T., Ed., The Career Is Dead - Long Live the Career, San Francisco, Jossey-Bass, (1996).

12. Hart, P., L. Svenning, and J. Ruchinskas, From Face-to-Face Meeting to Video Teleconferencing: Potential Shifts in the Meeting Genre, Management Communication Quarterly, 8 (1995), pp. 395-434. 
13. Inside the Knowledge Factory, The Economist, (October 4, 1997).

14. Johnston, Joseph S., Jr., Beyond Borders: Profiles in International Education, Association of American Colleges and American Assembly of Collegiate Schools of Business, (1993).

15. Leidner, D. and S. Jarvenpaa, The Use of Information Technology to Enhance Management School Education: A Theoretical View, MIS Quarterly, 19 (1995), pp. 265-292.

16. Lezberg, A., Quality Control in Distance Education: The Role of Regional Accreditation. American Journal of Distance Education, 12, 2 (1998), pp. 26-35.

17. McAllister, Linda and Linda Matthews, Electronic MBAs: The Future is Here, SAM Advanced Management Journal, 66, 1 (Winter 2001), p. 41.

18. Myers, Randy, The Absent Professors, ECFO, (Winter 2000), p. 63.

19. Neal, Ed, Distance Learning: Prospects and Problems, Phi Kappa Phi Journal National Forum, (Winter 1999), pp. 40-43.

20. Olsen, F., Virtual Institutions Challenge Accreditors to Devise New Ways of Measuring Quality, The Chronicle of Higher Education, (1999).

21. Porter, L., Creating the Virtual Classroom: Distance Learning with the Internet, New York: Wiley Computer Publishing, (1997).

22. Ryan, R., Student Assessment Comparison of Lecture and Online Construction Equipment and Methods Classes, T.H.E. Journal, 27, 6 (2000), pp. 78-83.

23. Schmotter, James W., An Assignment for the New Century, Selections, (Summer 2000), pp. 36-39.

24. Terry, N., Do Virtual Courses Lead to Virtual Learning? Journal of Business Education, 1, 2 (2000), pp. 5058 .

25. U.S. Department of Education, National Center for Education Statistics, U. S. Department of Education, Digest of Education Statistics, (1998), Table 186.

26. U.S. Department of Labor, Bureau of Labor Statistics (May 17, 2000) College Enrollment and Work Activity of 1999 High School Graduates.

27. The University - Alternative Futures, Futures, 30, 7 (September 1998).

28. Weber, T. E., Allen is Wooing Elite Colleges to Teach Online, Wall Street Journal, (July 28, 2000), p. B1.

29. Webster, J. and P. Hackley, Teaching Effectiveness in Technology-Mediated Distance Learning, Academy of Management Journal, 40, 6 (1997), pp. 1282-1309.

30. White, C., Learn Online: Students and Faculty Respond to Online Distance Courses at Grant MacEwan Community College, T.H.E. Journal, 27, 9 (2000), pp. 66-70. 
NOTES 